University of Nebraska - Lincoln

DigitalCommons@University of Nebraska - Lincoln

USDA National Wildlife Research Center - Staff Publications
U.S. Department of Agriculture: Animal and Plant Health Inspection Service

April 2006

\title{
Microsatellite Variation of Double-Crested Cormorant Populations in Eastern North America
}

\author{
M. Clay Green \\ University of Louisiana, Lafayette, LA \\ Juliann L. Waits \\ University of Louisiana, Lafayette, LA \\ Michael L. Avery \\ USDA/APHIS/WS National Wildlife Research Center, michael.I.avery@aphis.usda.gov \\ Mark E. Tobin \\ U.S. Department of Agriculture, National Wildlife Research Center \\ Paul L. Leberg \\ University of Louisiana, Lafayette, LA
}

Follow this and additional works at: https://digitalcommons.unl.edu/icwdm_usdanwrc

Part of the Environmental Sciences Commons

Green, M. Clay; Waits, Juliann L.; Avery, Michael L.; Tobin, Mark E.; and Leberg, Paul L., "Microsatellite Variation of Double-Crested Cormorant Populations in Eastern North America" (2006). USDA National Wildlife Research Center - Staff Publications. 420.

https://digitalcommons.unl.edu/icwdm_usdanwrc/420

This Article is brought to you for free and open access by the U.S. Department of Agriculture: Animal and Plant Health Inspection Service at DigitalCommons@University of Nebraska - Lincoln. It has been accepted for inclusion in USDA National Wildlife Research Center - Staff Publications by an authorized administrator of DigitalCommons@University of Nebraska - Lincoln. 


\title{
Microsatellite Variation of Double-Crested Cormorant Populations in Eastern North America
}

\author{
M. CLAY GREEN, ${ }^{\mathbf{1}, 2}$ Department of Biology, University of Louisiana, Lafayette, LA 70504-2451, USA \\ JULIANN L. WAITS, ${ }^{3}$ Department of Biology, University of Louisiana, Lafayette, LA 70504-2451, USA \\ MICHAEL L. AVERY, U.S. Department of Agriculture, National Wildlife Research Center, Gainesville, FL 32641, USA \\ MARK E. TOBIN, U.S. Department of Agriculture, National Wildlife Research Center, Ft. Collins, CO 80521, USA \\ PAUL L. LEBERG, Department of Biology, University of Louisiana, Lafayette, LA 70504-2451, USA
}

(JOURNAL OF WILDLIFE MANAGEMENT 70(2):579-583; 2006)

\section{Key words}

double-crested cormorant, microsatellite, Phalacrocorax auritus.

Double-crested cormorants (Phalacrocorax auritus) exhibit highly adaptive and opportunistic foraging behavior. This flexibility in foraging and increases in population size have led to conflicts with aquaculture and recreational and commercial fishing (Duffy 1995). Although double-crested cormorants roosting in the lower Mississippi Valley appear to have minimal negative impact on sport fisheries, they may have a significant impact on commercial aquaculture production in this region (Glahn and Brugger 1995, Glahn et al. 1998). In 2003, the U.S. Fish and Wildlife Service released the Final Environmental Impact Statement on doublecrested cormorant management allowing more flexibility in control of these birds in areas where they are negatively impacting aquaculture, habitat for nesting colonial waterbirds, and other public resources (U.S. Fish and Wildlife Service 2003). The U.S. Fish and Wildlife Service's Final Rule expands the 1998 Public Resource Depredation Order (50 CFR 21.47) to permit control of double-crested cormorants at winter roost sites in the vicinity of aquaculture facilities.

Populations of double-crested cormorants declined sharply in the 19th and early 20th centuries followed by several periods of population growth in the middle and later decades of the 20th century (Hatch 1995). Atlantic and Interior/Great Lakes migratory populations have seen the greatest increase in breeding pairs. Between the 1970s and 1990s, double-crested cormorant populations in the Atlantic increased 4-fold to more than 96,000 pairs (Hatch 1995). Although double-crested cormorants experienced a marked increase in population size from the 1970s to the 1990s, recent estimates suggest a reduction in the overall rate of growth (Tyson et al. 1999).

Although most populations of double-crested cormorants are migratory, a resident population ( $P$. auritus subsp. floridanus) estimated at 10,000-30,000 individuals occurs in Florida (Brugger 1995, Hatch 1995). Population estimates for Florida suggest stable resident populations of $P$. auritus subsp. floridanus with increasing numbers of wintering birds from migratory subpopulations (Brugger 1995). It is unclear whether or not the resident

\footnotetext{
${ }^{1}$ E-mail: claygreen@txstate.edu

2 Present address: Department of Biology, Texas State University, San Marcos, TX 78666, USA

${ }^{3}$ Present address: Department of Biology, University of Memphis, Memphis, TN 38152, USA
}

subspecies in Florida is a genetically distinct lineage, separate from migratory populations. If genetic differentiation is sufficient, it is possible that this resident population may warrant special consideration in management and any control efforts. In addition to the population in Florida, smaller colonies of nonmigratory birds have become established in other areas of the southeastern United States (e.g., Mississippi Delta, Reinhold et al. 1998; Louisiana, Hatch and Weseloh 1999).

Determining genetic distinctiveness of diverse populations of double-crested cormorants and the extent of gene flow are important for regional management decisions (Hatch and Weseloh 1999). It is thought that individuals exhibit high fidelity to a colony site; although, no data exist to support this claim (Hatch and Weseloh 1999). Reduction of populations on breeding grounds might prove more feasible than reduction of wintering birds because double-crested cormorants nest in distinct colonies that can be readily accessed. Control efforts on breeding grounds would be most effective at reducing depredation if the natal areas of wintering birds can be identified. The number of band returns is insufficient to establish a relationship between double-crested cormorant nesting colonies in the northern United States and Canada and the wintering, depredating populations in the southeastern United States. Genetic markers have been used to associate wintering dunlin (Calidris alpina) and Canada geese (Branta canadensis) with breeding populations (Pierson et al. 2000, Wennerberg 2001). Sufficient genetic differentiation among breeding populations is necessary to correctly assign samples of wintering birds to their natal areas.

An analysis of variation in mitochondrial DNA (mtDNA) found no evidence of genetic differences among migratory and nonmigratory populations (Waits et al. 2003). However, microsatellite loci are known to evolve rapidly and, thus, may reveal population structure even in the absence of mtDNA structure. For example, Goostrey et al. (1998) used highly polymorphic microsatellite markers to assess population structure and differentiation in European populations of great cormorants (P. carbo subsp. sinensis and $P$. carbo subsp. carbo). They detected high levels of variation both within and among populations suggesting the potential for detecting differences among populations of double-crested cormorants. Our primary objectives are to 1) characterize the genetic 
variation of double-crested cormorant populations at breeding sites, and 2) determine whether differences among breeding populations for microsatellite variation are sufficient to assign wintering individuals to their respective breeding grounds. These objectives may provide a clearer understanding of the link between natal areas and depredation problems on wintering grounds. We also assess genetic differentiation between migratory populations and the resident subspecies in Florida and a newly established population on Lake Millwood, Arkansas, USA. If population differentiation between migratory and resident populations is great, it may be important to ensure that control activities on the wintering migratory populations do not threaten the loss of the smaller resident populations representing genetically unique lineages.

\section{Study Area}

We obtained samples of blood or tissue from cormorant fledglings from 10 breeding sites in central and eastern North America (Chase Lake, N. D.; Spider Island, Lake Michigan; Naubinway Light Island, Lake Michigan; Little Charity Island, Lake Huron; Wallis and Birnie Rocky, Georgian Bay, Lake Huron; Scotch Bonnet Island, Lake Ontario; Little Galloo Island, Lake Ontario; Oneida Lake, N. Y.; Young Island, Lake Champlain; Penobscot Bay, Me.) and from 5 breeding sites in Arkansas and Florida (St. Martin Keys, Fla.; Lake Griffin, Fla.; Sanibel Island, Fla.; Cocoa Beach, Fla.; Lake Milwood, Ark.), representing resident populations (Fig. 1). Some of the breeding sites were grouped together based on geographic proximity to increase sample sizes; this resulted in 9 sample populations (Fig. 1).

\section{Methods}

Sample collection was conducted in compliance with United States and Canadian permit requirements. Collaborators were instructed to collect only 1 individual per nest to minimize the chance of siblings being included in our analysis. Blood and/or tissue were maintained in cell lysis solution (Puregene, Gentra Systems, Minneapolis, Minnesota) for storage. DNA was extracted from all samples using Puregene (Gentra Systems, Minneapolis, Minnesota) DNA isolation protocol for whole blood with $7.5 \mathrm{M}$ ammonium acetate for DNA precipitation and resuspension in $\mathrm{dH}_{2} \mathrm{O}$. We used primers designed for microsatellite analysis of the great cormorant by Piertney et al. (1998). They had identified primers variable in double-crested cormorants: 3 dinucleotide $(\mathrm{PcD} 2, \mathrm{PcD} 5$, and $\mathrm{PcD} 6)$ and 3 tetranucleotide (PcT1, PcT3, and PcT4). We dropped 1 locus (PcD6) from our analysis because no variation was found among 100 individuals from different populations. We performed polymerase chain reaction (PCR) amplifications using a PerkinElmer (Wellesley, Massachusetts) 480 DNA Thermal Cycler in a total volume of $25 \mu \mathrm{L}$. We performed amplifications and microsatellite genotyping of fluorescently labeled amplification products using standard protocols provided by the manufacturer (Applied Biosystems, Foster City, California), including $1.0 \mu \mathrm{L}$ genomic DNA sample $(10-300 \mathrm{ng} / \mu \mathrm{L}), 100 \mu \mathrm{M}$ each deoxyribonucleotide triphosphate (dNTP), 10X PCR Gold Buffer, 6.0 pmol fluorescently labeled forward primer (6-FAM or TET ABI Dyes, Applied Biosystems, Foster City, California), 5.6 pmol unlabeled forward primer, 6.0 pmol unlabeled reverse primer, and 0.6 U AmpliTaq Gold DNA polymerase.

The PCR temperature profile for primer pairs used in our analysis was 11 minutes denature at $95^{\circ} \mathrm{C}$ followed by 40 cycles of 1-minute denature at $95^{\circ} \mathrm{C}, 90$ seconds at annealing temperature of $51^{\circ} \mathrm{C}, 2$ minutes ramp to $72^{\circ} \mathrm{C}$, and 10 minutes final extension at $72^{\circ} \mathrm{C}$. Amplified products were analyzed using GeneScan-500 (TAMRA) size standard with an ABI Prism 310 DNA Sequencer (Applied Biosystems, Foster City, California) using the program GeneScan Analysis 2.02.

Estimates of allelic richness for each population were adjusted for differences in sample size using rarefaction (Leberg 2002). We used Friedman's test to assess whether there were significant differences in adjusted mean number of alleles between populations (Zar 1996). We hypothesized that the recently established resident population in Arkansas may have undergone a founder event. To test this hypothesis, we used the program BOTTLENECK to assess whether all populations had experienced recent reductions in effective population sizes (Cornuet and Luikart 1996). Under the assumption of mutation-drift equilibrium, BOTTLENECK calculates the distribution of the expected heterozygosity from the observed number of alleles and sample size. We used the Stepwise Mutation Model (SMM) output of the Wilcoxon 1-tailed test because it is most appropriate for data sets of $<30$ individuals per population and $<10$ microsatellite loci (Pierson et al. 2000).

We used GENEPOP 3.1 to estimate $\mathrm{F}_{\text {is }}$ and $\mathrm{F}_{\text {st }}$ (Raymond and Rousset 1995). $F_{i s}$ is a measure of deviation from HardyWeinberg equilibrium (HWE); positive values indicate that the observed heterozygosity is lower than the Hardy-Weinberg expectations. We obtained estimates of HWE with the Markov chain method following the algorithm of Guo and Thompson (1992). We used GENEPOP to conduct Fisher's exact test for significant genic differentiation $\left(F_{s t}\right)$ between populations and between breeding sites within each population. The $\mathrm{F}_{\text {st }}$ values, a measure of interpopulation differentiation, were estimated by a weighted analysis of variance (Weir and Cockerham 1984). Tests of significance for pairwise comparisons of genic differentiation were adjusted according to the Bonferroni method (Rice 1989). We used the ISOLDE program in GENEPOP to examine possible correlations between geographic distances and average estimates of $\mathrm{F}_{\mathrm{st}}$, across loci, as expected under a model of isolation by distance (Rousset 1997).

All samples were amplified and analyzed at least 2 times to verify the accuracy of genotyping. In populations where observed allelic frequencies deviated significantly from HWE expectations, we used the program MICROCHECKER (Oosterhout et al 2004) to test the null hypotheses that deviations from HWE expectations were due to the presence of null alleles or the Wahlund effect. Allele and genotype frequencies that were identified as affected by the presence of null alleles were adjusted according to the Brookfield I method (Oosterhout et al 2004).

To evaluate whether individuals could be assigned to their source populations on the basis of genotype, we conducted an assignment test (Paetkau et al. 1995, 1997) for all populations. Because the assignment test is based on individual genotypes, only data uncorrected for the presence of null alleles were used for this analysis. 


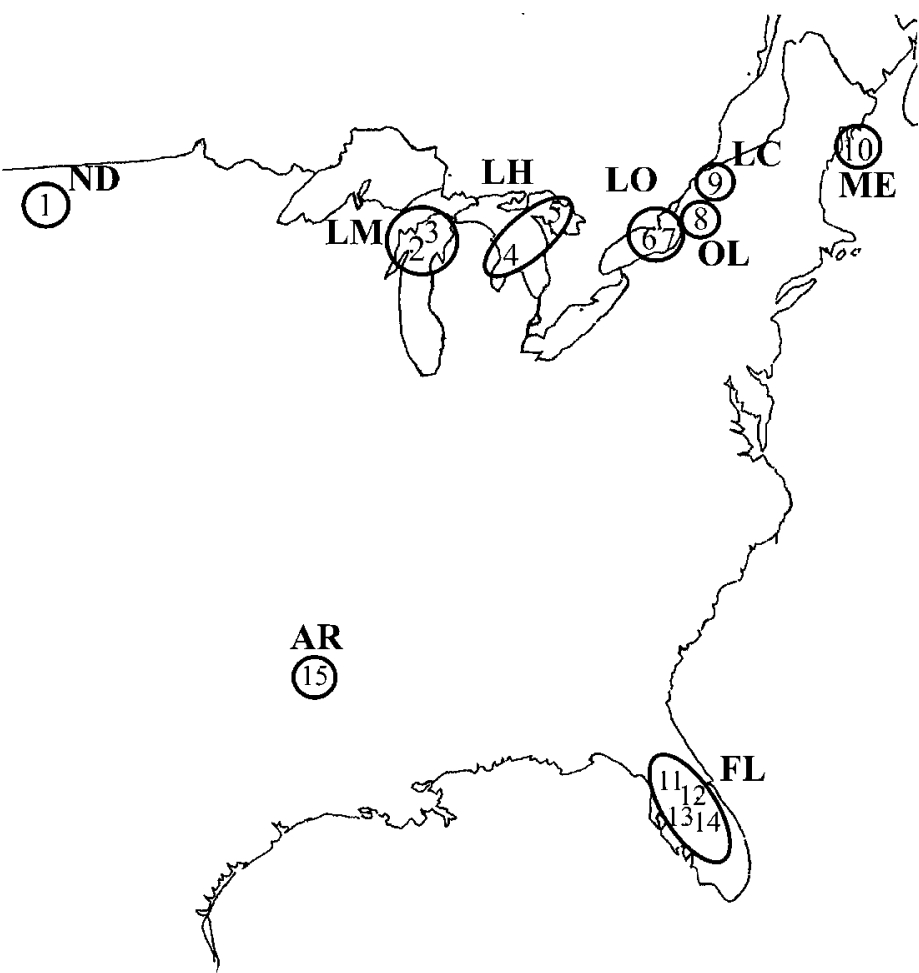

Figure 1. Map of North America showing the 15 sampling locations and subsequent grouping of the sampling locations into 9 populations (May 1998Aug 2000). Sample sizes are listed after each location in parenthesis. Sampling locations are as follows: 1) Chase Lake, N. D. (15); 2) Spider Island, Lake Michigan (18); 3) Naubinway Light Island, Lake Michigan (5); 4) Little Charity Island, Lake Huron (11); 5) Wallis and Birnie Rocky, Georgian Bay, Lake Huron (4); 6) Scotch Bonnet Island, Lake Ontario (16); 7) Little Galloo Island, Lake Ontario (4); 8) Oneida Lake, N. Y. (20); 9) Young Island, Lake Champlain (19); 10) Penobscot Bay, Me. (23); 11) St. Martin Keys, Fla. (6); 12) Lake Griffin, Fla. (7); 13) Sanibel Island, Fla. (2); 14) Cocoa Beach, Fla. (9); 15) Lake Milwood, Ark. (20). The following abbreviations were used for the 9 populations: ND, North Dakota; LM, Lake Michigan; LH, Lake Huron; LO, Lake Ontario; OL, Oneida Lake; LC, Lake Champlain; ME, Maine; FL, Central Florida; and AR, Lake Millwood, Arkansas.

\section{Results}

We determined complete genotypes at 5 microsatellite loci ( $\mathrm{PcD} 2$, PcD5, PcT1, PcT3, and PcT4) for 179 individuals from these 9 populations. The average number of alleles per locus was between 7.2 and 9.8 (Table 1). The mean number of alleles per locus, adjusted for sample size, varied between approximately 6.7 and 8.4 at each region, with Chase Lake (ND) having the highest, and Oneida Lake (OL) having the lowest. Allelic richness did not differ among populations (Friedman's test, $\chi^{2}=5.41, P>0.05$ ). Using BOTTLENECK, we found no evidence for recent bottlenecks in any populations ( $P>0.05$ for all populations).

Mean expected heterozygosity within populations ranged from $65 \%$ to $75 \%$, and mean observed heterozygosity ranged from $51 \%$ to $60 \%$. Four out of 5 microsatellite loci deviated significantly from HWE (Table 2). Deviations from HWE may be due to the presence of null alleles or the combination of subpopulations with different allele frequencies in the same population (e.g., Wahlund effect). Using MICROCHECKER, 17 out of 45 single-locus analyses indicated the possible presence of null alleles (Table 3). The null hypothesis test (i.e., no Wahlund effect) was not rejected for any of the 45 analyses, indicating deviations from HWE were not due to combining samples from genetically differentiated subpopulations.

Tests of $\mathrm{F}_{\text {st }}$ estimates indicated populations differed from one another at all 5 loci for uncorrected data and for data corrected for null alleles (Table 2). Pairwise comparisons between populations revealed genic differentiation for 10 and 27 of 36 possible tests on uncorrected data and data corrected for null alleles, respectively (Table 4). We found no correlation of geographic distance between populations and genetic differentiation (uncorrected $P=$ 0.336 , corrected $P=0.345$ ). The assignment test resulted in $<25 \%$ of individuals being correctly assigned to their populations.

\section{Discussion}

We found statistically significant genetic differentiation among populations, although the degree of differentiation was relatively small. For the migratory populations, pairwise comparisons of genic differentiation between populations suggest a high level of genetic exchange between Chase Lake and the Great Lakes, Oneida Lake, and Lake Champlain populations. The most distinct migratory population was Penobscot Bay. Although both Interior and Penobscot Bay populations are considered the same subspecies ( $P$. auritus subsp. auritus), these 2 populations are geographically distinct during the breeding season and overlap only in winter (Hatch 1995). Although genic differentiation was small between Interior and Atlantic populations, this differentiation may reflect reduced gene flow between Atlantic populations and populations in the Great Lakes.

Our results also do not reveal much genic differentiation

Table 1. Mean number of alleles; adjusted mean number of alleles, ${ }^{a}$ mean expected heterozygosity, and mean observed heterozygosity for 9 geographic populations (May 1998-Aug 2000) across 5 loci. See Figure 1 caption for region abbreviations.

\begin{tabular}{|c|c|c|c|c|c|c|c|c|c|}
\hline \multirow[b]{2}{*}{ Region sampled } & \multirow[b]{2}{*}{$\mathbf{n}$} & \multicolumn{2}{|c|}{ Mean no. of alleles } & \multicolumn{2}{|c|}{ Adjusted mean of alleles } & \multicolumn{2}{|c|}{$\mathbf{H}_{\mathbf{e}}$} & \multicolumn{2}{|c|}{$\mathbf{H}_{\mathbf{o}}$} \\
\hline & & Mean & SE & Mean & SE & Mean & SE & Mean & SE \\
\hline Chase Lake (ND) & 15 & 8.8 & 0.89 & 8.4 & 0.82 & 0.748 & 0.04 & 0.586 & 0.06 \\
\hline Lake Michigan (LM) & 23 & 9.8 & 1.09 & 8.2 & 0.84 & 0.749 & 0.05 & 0.597 & 0.07 \\
\hline Lake Huron (LH) & 15 & 7.2 & 0.73 & 6.9 & 0.69 & 0.698 & 0.06 & 0.602 & 0.07 \\
\hline Lake Ontario (LO) & 20 & 8.4 & 1.12 & 7.2 & 0.87 & 0.685 & 0.07 & 0.585 & 0.06 \\
\hline Oneida Lake (OL) & 20 & 7.4 & 0.83 & 6.7 & 0.73 & 0.715 & 0.04 & 0.510 & 0.07 \\
\hline Lake Champlain (LC) & 19 & 8.6 & 0.91 & 7.7 & 0.79 & 0.713 & 0.06 & 0.602 & 0.06 \\
\hline Penobscot Bay (ME) & 23 & 8.6 & 0.88 & 7.3 & 0.75 & 0.678 & 0.07 & 0.574 & 0.07 \\
\hline Lake Millwood (AR) & 20 & 7.4 & 0.64 & 7.4 & 0.58 & 0.721 & 0.04 & 0.570 & 0.05 \\
\hline Central Florida (FL) & 24 & 9.2 & 1.15 & 7.5 & 0.94 & 0.654 & 0.07 & 0.558 & 0.08 \\
\hline
\end{tabular}

${ }^{\text {a }}$ Adjusted to our smallest sample size (13) for which we had at 1 population for 1 locus. 
Table 2. Mean values of deviations from Hardy-Weinberg equilibrium $\left(F_{i s}\right)$ and genetic differentiation $\left(F_{\text {st }}\right)$ for the 9 geographic populations (May 1998-Aug 2000) that were uncorrected and corrected for the presence of null alleles. $P$ values represent significant deviations from the expected value of zero.

\begin{tabular}{|c|c|c|c|c|c|c|c|c|}
\hline \multirow[b]{2}{*}{ Locus } & \multicolumn{4}{|c|}{ Uncorrected } & \multicolumn{4}{|c|}{ Corrected } \\
\hline & $F_{\text {is }}$ & $P$ & $\mathbf{F}_{\text {st }}$ & $P$ & $F_{\text {is }}$ & $P$ & $\mathbf{F}_{\mathbf{s t}}$ & $P$ \\
\hline PcD2 & 0.364 & 0.000 & 0.021 & 0.001 & 0.105 & 0.003 & 0.022 & 0.001 \\
\hline PCT1 & 0.277 & 0.000 & 0.064 & 0.000 & 0.106 & 0.041 & 0.060 & 0.001 \\
\hline РсT3 & 0.000 & 0.863 & 0.013 & 0.023 & 0.000 & 0.837 & 0.013 & 0.019 \\
\hline PCT4 & 0.077 & 0.006 & 0.011 & 0.000 & 0.067 & 0.045 & 0.010 & 0.001 \\
\hline PCD5 & 0.513 & 0.001 & 0.029 & 0.001 & 0.001 & 0.015 & 0.149 & 0.001 \\
\hline
\end{tabular}

between subspecies $P$. auritus subsp. auritus in migratory populations and the resident subspecies $P$. auritus subsp. floridanus in Central Florida. We saw no evidence that the Central Florida population was any more genetically distinct than any of the migratory populations or the resident Arkansas population. The amount of genetic structure was insufficient to allow for correct assignment of individuals to their populations.

We found resident populations contained few alleles that were rare or unobserved in the migratory populations. However, the resident populations were sufficiently differentiated from each other and from the migratory breeding populations, so it is likely that the dynamics of 1 resident population were largely unaffected by changes in the other populations.

The only previous genetic study on double-crested cormorant populations, focusing on mtDNA, found little genetic variation (Waits et al. 2003). We found high levels of microsatellite variation in each population. A survey of European populations of the great cormorant reported observed heterozygosity levels between $64 \%$ and $95 \%$ using the same microsatellite loci (Goostrey et al. 1998). The populations of double-crested cormorants we examined were on the lower range of genetic variability seen in its European congener.

Deviations from HWE were largely due to the presence of null allele(s). There was little evidence supporting the presence of a Wahlund effect. We used both the uncorrected and corrected (presence of null alleles) allele frequency data in our analyses of genic differentiation. Our results did not change appreciatively,
Table 3. Estimated frequencies of null alleles for each population ${ }^{\mathrm{a}}$ (May 1998Aug 2000) at each locus where hypothesis tests in MICROCHECKER suggested the presence of null alleles $(P<0.05)$. Dashes indicate no evidence for the presence of null alleles.

\begin{tabular}{lccccc}
\hline & \multicolumn{5}{c}{ Locus } \\
\cline { 2 - 6 } Population & PcD2 & PcT1 & PcT3 & PcT4 & PcD5 \\
\hline ND & 0.148 & - & - & 0.087 & 0.163 \\
LM & 0.139 & 0.100 & - & - & - \\
LH & - & 0.194 & - & - & - \\
LO & - & 0.181 & - & - & - \\
OL & 0.243 & 0.145 & - & - & 0.202 \\
LC & 0.182 & 0.130 & - & - & - \\
ME & 0.232 & - & - & - & - \\
AR & - & - & - & 0.116 & 0.153 \\
FL & 0.160 & - & - & - & - \\
\hline
\end{tabular}

${ }^{a}$ ND, North Dakota; LM, Lake Michigan; LH, Lake Huron; LO, Lake Ontario; OL, Oneida Lake; LC, Lake Champlain; ME, Maine; AR, Lake Millwood, Arkansas; FL, central Florida.

but genetic differentiation did increase slightly when null allele frequencies were included in our analysis. It is not surprising that the presence of null alleles had little effect on our study given that the distribution of null alleles across the populations is likely to be influenced by the same processes that affect observed alleles. Use of uncorrected or corrected data for the presence of null alleles did not affect our conclusions that levels of genetic differentiation and geographic isolation were low.

\section{Management Implications}

If management of double-crested cormorants necessitates selective control of depredating individuals or populations, a relatively accurate assignment of depredating individuals to their respective breeding grounds is required. However, we conclude that genetic tests to assign wintering individuals to their respective natal areas are unlikely to be informative without huge molecular data sets. Because movement is somewhat limited between the 2 resident populations and between the resident and migratory populations, we recommend that managers justify managing each resident population as a separate entity; although, there is no evidence that either contain unique phenotypes that would require special protection.

Table 4. Multilocus estimates of genic differentiation $\left(F_{s t}\right)$ between population ${ }^{a}$ pairs (May 1998-Aug 2000) at 5 microsatellite loci using data that were uncorrected (above diagonal) and corrected (below diagonal) for the presence of null alleles. Underlined $F_{\text {st }}$ values indicate significant differentiation ( $\alpha=0.05$ ) after sequential Bonferroni correction for 36 multiple tests.

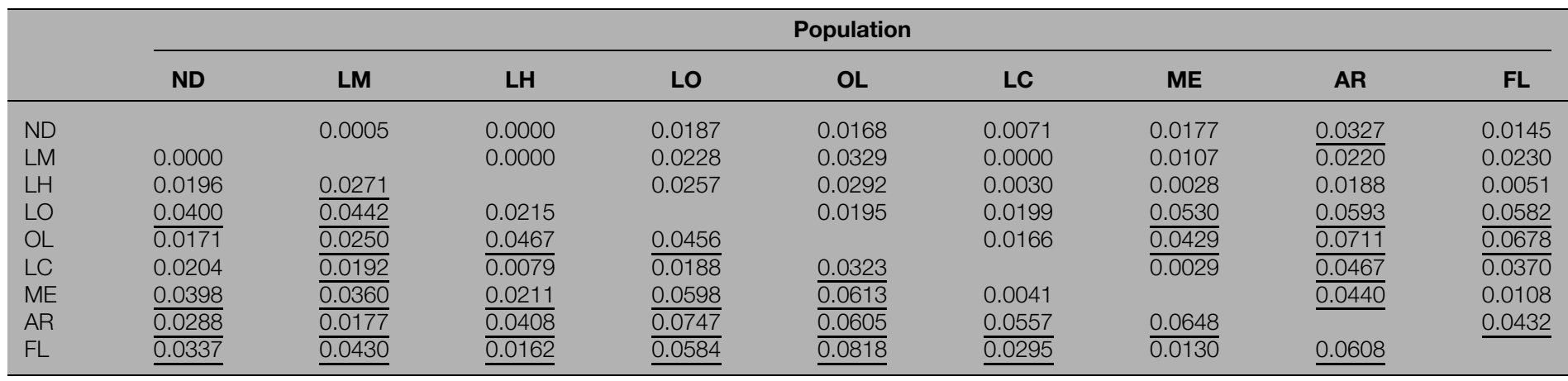

${ }^{a}$ ND, North Dakota; LM, Lake Michigan; LH, Lake Huron; LO, Lake Ontario; OL, Oneida Lake; LC, Lake Champlain; ME, Maine; AR, Lake Millwood, Arkansas; FL, central Florida. 


\section{Acknowledgments}

We thank all those individuals who collected samples including B. Allen, Maine Department Inland Fisheries and Wildlife; D. V. C. Weseloh, Environment Canada; J. H. Bedard, University Laval; B. A. Hanbidge, Ducks Unlimited Canada; B. F. Blackwell, U.S. Department of Agriculture, Sandusky, Ohio; K. L. Stromborg, U.S. Fish and Wildlife Service, Green Bay, Wisconsin; L. Williams and D. Best, U.S. Fish and Wildlife Service, East

\section{Literature Cited}

Brugger, K. E. 1995. Double-crested cormorants and fisheries in Florida. Colonial Waterbirds 18(S1):110-117.

Cornuet, J. M., and G. Luikart. 1996. Description and power analysis of two tests for detecting recent population bottlenecks from allele frequency data. Genetics 144:2001-2014.

Duffy, D. C. 1995. Why is the double-crested cormorant a problem? Insight from cormorant ecology and human sociology. Colonial Waterbirds 18(S1): 25-32.

Glahn, J. F., and K. E. Brugger. 1995. The impact of double-crested cormorants on the Mississippi Delta catfish industry: a bioenergetics model. Colonial Waterbirds 18(S1):168-175.

Glahn, J. F., J. B. Harrel, and C. Vyles. 1998. The diet of wintering doublecrested cormorant feeding at lakes in the southeastern United States. Colonial Waterbirds 21:431-437.

Goostrey, A., D. N. Carss, L. R. Noble, and S. B. Piertney. 1998. Population introgression and differentiation in the great cormorant Phalacrocorax carbo in Europe. Molecular Ecology 7:329-338.

Guo, S. W., and E. A. Thompson. 1992. Performing the exact test of HardyWeinberg proportions for multiple alleles. Biometrics 53:325-338.

Hatch, J. J. 1995. Changing populations of double-crested cormorants. Colonial Waterbirds 18(S1):8-24.

Hatch, J. J., and D. V. Weseloh. 1999. Double-crested cormorant (Phalacrocorax auritus). In A. Poole, and F. Gill, editors. The Birds of North America, No. 441. The Birds of North America, Philadelphia, Pennsylvania, USA.

Leberg, P. L. 2002. Estimating allelic richness: effects of sample size and bottlenecks. Molecular Ecology 11:2445-2449.

Oosterhout, C. V., W. F. Hutchinson, D. P. M. Wills, and P. Shipley. 2004. Micro-Checker: software for identifying and correcting genotyping errors in microsatellite data. Molecular Ecology Notes 4:535-538.

Paetkau, D., W. Calvert, I. Stirling, and C. Strobeck. 1995. Microsatellite analysis of population structure in Canadian polar bears. Molecular Ecology 4:347-354.

Paetkau, D., L. P. Waits, P. L. Clarkson, L. Craighead, and C. Strobeck. 1997. An empirical evaluation of genetic distance statistics using microsatellite data from bear (Ursidae) populations. Genetics 147:1943-1957.
Lansing, Michigan; B. Svenson, Winnipeg, Manitoba; F. Cuthbert, University of Michigan; M. Hoy, U.S. Department of Agriculture Stuttgart, Arkansas; T. King, U.S. Department of Agriculture Starkville, Mississippi; and J. Coleman, Cornell University. Funding for research and manuscript preparation was provided by the U.S. Department of Agriculture, National Wildlife Research Center and the Environmental Protection Agency (R-82942001).

Pierson, B. J., J. M. Pearce, S. L. Talbot, G. F. Shields, and K. T. Scribner. 2000. Molecular genetic status of Aleutian Canada Geese from Buldir and the Semidi Islands, Alaska. Condor 102:172-180.

Piertney, S. B., A. Goostrey, J. F. Dallas, and D. N. Carss. 1998. Highly polymorphic microsatellite markers in the great cormorant Phalacrocorax carbo. Molecular Ecology 7:138-140.

Raymond, M., and F. Rousset. 1995. Genepop (Version 3.1): population genetic software for exact tests and ecumenicist. Journal of Heredity 86: 248-249.

Reinhold, D. S., A. J. Mueller, and G. Ellis. 1998. Observations of nesting double-crested cormorants in the delta region of Mississippi. Colonial Waterbirds 21:450-451.

Rice, W. R. 1989. Analyzing table of statistical tests. Evolution 43:223-225.

Rousset, F. 1997. Genetic differentiation and estimation of gene flow from Fstatistics under isolation by distance. Genetics 145:1219-1228.

Tyson, L. A., J. L. Belant, F. J. Cuthbert, and D. V. Weseloh. 1999. Nesting populations of double-crested cormorants in the United States and Canada. Pages 17-25 in Symposium on double-crested cormorants: population status and management issues in the Midwest. U.S. Department of Agriculture, Animal and Plant Health Inspection Services Technical Bulletin 1879, Washington, D.C., USA.

U.S. Fish and Wildlife Service. 2003. Final environmental impact statement (DEIS) on double-crested cormorant management. Washington, D.C., USA.

Waits, J. L., M. L. Avery, M. E. Tobin, and P. L. Leberg. 2003. Low mitochondrial DNA variation in double-crested cormorants in eastern North America. Waterbirds 26:196-200.

Weir, B. S., and C. C. Cockerham. 1984. Estimating F-statistics for the analysis of population structure. Evolution 38:1358-1370.

Wennerberg, L. 2001. Breeding origin and migration pattern of dunlin (Calidris alpina) revealed by mitochondrial DNA analysis. Molecular Ecology 10:11111120.

Zar, J. H. 1996. Biostatistical analysis. Third edition. Prentice-Hall, Upper Saddle River, New Jersey, USA.

Associate Editor: DeWoody. 